\title{
Clinical, and biochemical evaluation of growth and development in prepubertal children who underwent adenotonsillectomy
}

\author{
Adenotonsillektomi yapılan prepubertal çocuklarda büyüme ve \\ gelişmenin klinik ve biyokimyasal değerlendirmesi
}

\author{
Neslihan YAPRAK ${ }^{1}$, Osman İlkay ÖZDAMAR ${ }^{2}$, Muhammet TEKIN ${ }^{2}$
}

\begin{abstract}
Although, in practice it has been believed that linear growth, and weight of the children who underwent adenotonsillectomy increase, however this presumption has not been proved by adequate number of studies performed using objective parametres. The aim of this study is to determine the effect of adenotonsillectomy upon growth and growth biomarkers. This study was carried out from January 2007 to January 2008 in a tertiary care hospital. Twenty-eight prepubertal children including 20 boys and 8 girls participated in our study. The mean age at surgery was $6.78 \pm 2.58$ years (range $4-13$ years). Weight and height measurements of all subjects, and also IGF-1 and IGFBP-3 serum levels with standard deviation scores were evaluated before and 1-6 months after adenotonsillectomy. Serum levels of IGF-1 and IGFBP-3 were significantly higher at 1 month and 6 months after adenotonsillectomy compared to preoperative levels $(p<0.001)$. Also Serum levels of IGF-1 and IGFBP-3 were significantly higher at postoperative 6 months compared to at postoperative 1 month $(p<0.001)$. A positive correlation detected between the rise of serum levels of IGF-1 and IGFBP-3, and the weight gain and linear growth in all of the 28 patients who were included in this study. A positive correlation was demonstrated between increments in weight and length and IGF-1 and IGFBP-3 serum.
\end{abstract}

Keywords: Insulin like growth factor-I, insulin like growth factor binding protein-3, adenotonsillectomy öz

Adenotonsillektomi ameliyatı sonrasında çocuklarda lineer büyüme ve kilo alımının sağlandığına pratikte inanılmasına rağmen, bunu kanıtlayacak objektif parametrelerle yapılmış yeterli sayıda çalışma bulunmamaktadır. Bu çalışmanın amacı, adenotonsillektomi operasyonunun büyüme ve büyüme biyo-belirteçleri üzerindeki etkisini belirlemektir. Bu çalışma, Ocak 2007 ve Ocak 2008 tarihleri arasında üçüncü basamak sağlık kurumu olan bir hastanede gerçekleştirilmiştir. Yirmi erkek ve 8 kız çocuğu olmak üzere toplam yirmi sekiz çocuk çalışmaya dâhil edilmiştir. Cerrahi

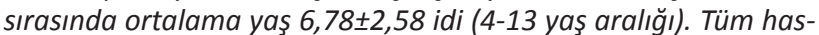
taların kilo ve boy ölçümleri ve IGF-1 ve IGFBP-3 serum düzeyleri, standart sapma skorlarıla birlikte ameliyattan 1-6 ay önce ve 1-6 ay sonra değerlendirilmiştir. Serum IGF-1 ve IGFBP-3 düzeylerinde, postoperatif 1. ayda ve 6. ayda ameliyat öncesi düzeylere kıyasla anlamlı artışlar tespit edilmiştir $(p<0,001)$. Ayrıca, postoperatif 6. ayda serum IGF-1 ve IGFBP-3 seviyeleri, postopertif 1. aydaki düzeylere kıyasla anlamlı ölçüde daha yüksek bulunmuştur ( $p<0,001)$. Serum IGF-1 ve IGFBP-3 seviyeleri ile kilo artışı ve lineer büyüme arasında pozitif bir korelasyon tespit edilmiştir. Bu çalışmaya alınan 28 hastanın tamamında, yalnızca kilo ve boy ölçümlerindeki artış değil aynı zamanda IGF-1 ve IGFBP-3 serum düzeylerindeki artışın, postoperatif 1. ay ve 6. ayda istatistiksel olarak anlamlı olduğu gösterilmiştir $(p<0,001)$. Ayrıca, IGF-1 ve IGFBP-3 serum düzeylerindeki artış ile kilo alımı ve lineer büyüme arasında pozitif yönde bir korelasyon bulunmuştur.

Anahtar kelimeler: Insülin benzeri büyüme faktörü-l, insülin benzeri büyüme faktörü bağlayıcı proteini-3, adenotonsillektomi

\section{Giriş}

Adenotonsillektomi kulak burun boğaz (KBB) alanında çocukluk döneminde en sık yapılan ameliyatlar- dan biridir. Bu endikasyonların birçoğunun doğrudan veya başka sistem etkileri ile çocuğun büyümesi üzerinde olumsuz etkileri bulunmaktadır. Adenotonsillektomi operasyonlarının çocuğun büyümesi üzerin-

Received: 14.04 .2016

Accepted: 28.07 .2016

${ }^{1}$ Akdeniz University, Faculty of Medicine, Department of Otorhinolaryngology

${ }^{2}$ Istanbul Medeniyet University, Faculty of Medicine, Goztepe Educational and Research Hospital, Department of Otorhinolaryngology

Yazışma adresi: Neslihan Yaprak, Akdeniz University, Faculty of Medicine, Department of Otorhinolaryngology, Antalya

e-mail: neslihanyaprak@yahoo.com 
de olumlu etkisinin olduğu KBB uzmanları tarafından pratikte gözlemlenmektedir. Bu gözlemi klinik ve endokrinolojik değerlendirme parametresi olan biyokimyasal değerlerle ortaya koymak amacıyla hastaların postoperatif kilo ve boyları ile IGF-1 ve IGFBP-3 serum düzeyleri ölçülerek preoperatif düzeylerle karşılaştırılmıştır ${ }^{1,2}$.

Bu çalışmanın amacı, adenoid ve tonsil kaynaklı hastalıklar nedeniyle adenoidektomi tonsillektomi uygulanmış çocukların, postoperatif dönemde büyüme hızlarının ve gelişim değişikliklerinin klinik açıdan ve biyokimyasal veriler ışığında takiplerini yaparak, ameliyatın büyüme ve gelişim üzerindeki olumluolumsuz etkilerini preoperatif degerlerle karşılaştırarak değerlendirmektir Bu nedenle çalışmaya dâhil edilen çocuk hastaların hepsinin preoperatif boy-kilo ölçümleri ve IGF-1 ile IGF-BP3 değerleri postoperatif erken ve geç dönem değerleri ile karşılaştırıldı.

\section{GEREÇ ve YÖNTEMLER}

Çalışmaya, adenoid vejetasyon, kronik tonsillit ve hipertrofik tonsil nedeniyle Ocak 2007 ve Ocak 2008 arasında kliniğimizde ameliyat edilmiş yirmi sekiz prebupertal çocuk (4-13 yaş aralığında 20 erkek ve $8 \mathrm{kız} \mathrm{çocuğu)} \mathrm{(ortalama} \mathrm{yaş} 6,78 \pm 2,58$ ) dâhil edilmiştir. Çalışmaya başlamadan önce lokal etik kurul onayı alınmıştır. Etik kurul onay tarihi $27 / 03 / 2008$ ve onay numarası 45/K'dir.

Operasyon için endikasyonu uygun ve çalışmaya dahil edilmiş hastaların ebeveynlerinden en az birinden beslenme alışkanlıkları, uyku düzeni, yaş, cinsiyet, gibi genel bilgiler ile çocuğun özgeçmişi ve aile öyküsüne ilişkin bilgiler öğrenildi. Özgeçmişinde alerjik astım, kardiak veya renal yetmezliği, alerjik rinit ve diayabet gibi kronik hastalığı olan çocuklar çalışmaya dahil edilmemiştir. Tüm çocukların anamnezinde bir yıl içerisindeki tonsillit atağı sayısı, uykuda nefes durması, ağız solunumu, burun tıkanıklığı, nazal akıntısı, sık hapşırık, burunda kaşınma, gözlerde sulanma, işitmede güçlük, yutma güçlüğü ve iştah azlığı sorgulanmıştır.
Hastaların tamamına anterior rinoskopi, otoskopi ve orofarengeal muayene yapılmıştır. Ayrıca fiziksel muayenede işitme sorunu olduğu tespit edilen hastalara timpanometrik ve odyometrik ölçümler yapılmış ve yutma güçlüğü ile uyku apnesi olan hastalara nazofarenks ve larenks endoskopi uygulanmıştır. Anterior rinoskopik muayenede nazal tıkanıklık yapacak alt konka hipertrofisi ve septal deviasyona sahip hastalar çalışmaya alınmamıştır.

Tonsiller hipertrofi değerlendirmesinde, Brodsky ve ark. $^{3}$ tarafından önerilen sınıflandırma referans alınmıştır. Bu sınıflandırmaya göre, tonsiller hipertrofi şu şekilde sınıflandırımaktadır: Tonsil hava yolunda görünmüyorsa (plikadan hava yoluna doğru uzanmıyorsa) tonsil büyüklüğü $0, \% 25$ ten daha az hava yolu obstrüksiyonayol açan tonsiller 1+, \%25 -\%50 hava yolu obstrüksiyonuna yol açan tonsiller 2+, \%50 -\%75 hava yolu obstrüksiyonuna yol açan tonsiller 3+, $\% 75$ 'in üzerinde havayolu obstrüksiyonu yapan tonsiller ise 4+ olarak değerlendirilmektedir. Çalışmaya dâhil edilen hastaların tamamına adenoidektomi ve tonsillektomi aynı seansta yapılmıştır.

Çocukların adenoid dokusu boyutları, yumuşak doku dozunda lateral servikal direkt grafi ve ameliyat esnasındaki palpasyon ile belirlenmiştir. Hastaların tonsil boyutu $3+$ ve üzeri olanlar, hipertrofik tonsil kabul edilip ameliyata alınırken, tonsil büyüklüğü 3+ altında olan hastalar semptom ve öykülerine göre kronik tonsillit tanısı ile ameliyata alınmıştır.

Hastaların tamamının ameliyat öncesi kilo ve boy ölçümleri yapılmıştır. Ameliyat öncesinde ve postoperatif 1. ve 6 . aylarda kilo ölçümü 0,5 kg'ye duyarlı klinik baskül kullanarak, boy ise $1,0 \mathrm{~mm}$ 'ye duyarlı Harpendan duvara monte stadiometre kullanılarak yapılmıştır. Verilerin toplanması amacıyla hastaların hepsinden jelli tüpe periferik venöz kan alınmıştır. Postoperatif 1 . ay ve 6 . aylarda aynı işlemler yinelenmiştir. Hastalardan alınan venöz kan santrifüj edildikten sonra, örnekler -20C'de saklanarak hepsinin ölçümü beraber çalışılmıştır. Tüm ölçümler, hastanemizdeki biyokimya laboratuvarında aynı teknisyen tarafından gerçekleştirilmiştir. 
Bu çalışmada, Türk çocuklarının büyüme persantili kullanıımış olması çalışmanın limitasyonudur. Boy ve kilosu 3. ve 97. persantil arasında olan çocuklar seçilmiş ve diğerleri çalışmadan dışlanmıştır. Elde edilen tüm veriler (kilo, boy, IGFBP-3 ve IGF-1 değerleri) istatiksel olarak değerlendirildi.

Çalışmada elde edilen veriler değerlendirilirken istatistiksel analizler için SPSS (statistical package for social sciences) for Windows 15.0 programından faydalanıldı. Çalışma verileri değerlendirilirken, tanımlayıcı istatistiksel metotların (ortalama, standart sapma) dışında niceliksel verilerin karşılaştırmasında, yinelemeli ölçümlerde varyans analizi ve farklılığa neden çıkan grubun tespitinde pairedsample +testi kullanıdı. Sonuçta \%95 güven aralığında anlamlılık $p<0,05$ düzeyinde değerlendirildi.

\section{BULGULAR}

Ameliyat öncesi, sonrası 1 . ay ve 6 . ay IGF-1 seviyelerinde istatistiksel açıdan ciddi anlamda farklılık ortaya konmuştur $(p<0,01)$. Ameliyat öncesi IGF-1 seviyesine göre ameliyat sonrası 1 . ay $(p: 0,001 ; p<0,01)$ ve 6. ay $(p: 0,001 ; p<0,01)$ IGF-1 seviyelerinde izlenen artış istatistiksel açıdan yüksek düzeyde farklılık göstermiştir (Figür 1). Postoperatif 1. ay IGF-1 seviyesine göre ameliyat sonrası 6 . ay ( $p: 0,001 ; p<0,01)$ IGF-1 seviyesinde izlenen yükseliş istatistiksel açıdan anlamlıdır (Tablo 1).

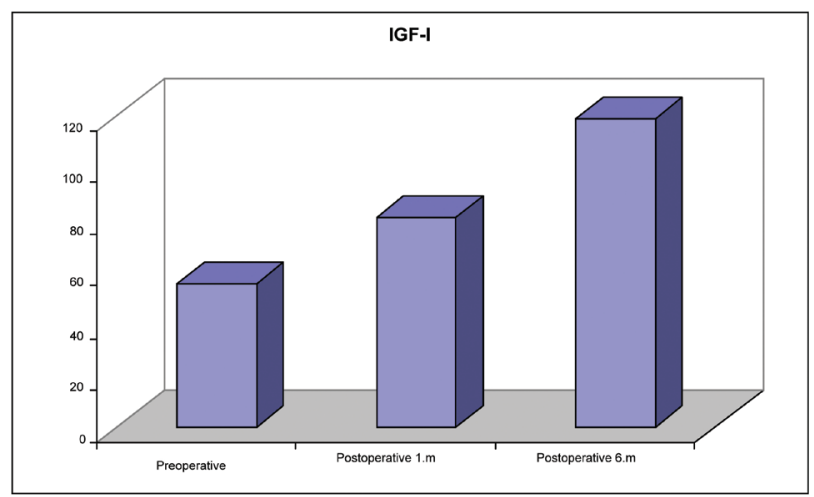

Figür 1. IGF-I değerleri grafiği.
Tablo 1. Preop, postop 1. ay ve postop 6. ay serum IGF-I değerleri.

\begin{tabular}{lll}
\hline & \multicolumn{1}{c}{$\begin{array}{c}\text { IGF-I } \\
\text { Mean } \pm \text { SD }\end{array}$} & p* \\
\hline Preoperatif & $55,41 \pm 24,63$ & \\
Postoperatif 1. ay & $80,89 \pm 25,43$ & $0,001^{* *}$ \\
Postoperatif 6. ay & $119,11 \pm 40,43$ & \\
Preop-Postop 1. ay $\mathrm{p}^{++}$ & $0,001^{* *}$ & \\
Preop-Postop 6. ay $\mathrm{p}^{++}$ & $0,001^{* *}$ & \\
Postop 1. ay-Postop 6. ay $\mathrm{p}^{++}$ & $0,001^{* *}$ & \\
& & \\
\hline
\end{tabular}

${ }^{+}$Variation Analysis for Repetitive Measurements

${ }^{++}$Paired Sample t test

$* * p<0,01$

Ameliyat öncesi, ameliyat sonrası 1 . ay ve 6 . ay IGFBP-3 seviyelerinde istatistiksel açıdan ciddi düzeyde anlamlı farklılık izlenmektedir $(p<0,01)$. Ameliyat öncesi IGFBP-3 seviyesine göre ameliyat sonrası 1 . ay ( $p: 0,001 ; p<0,01)$ ve 6 . ay ( $p: 0,001 ; p<0,01)$ IGFBP-3 seviyelerinde izlenen yükselmeler istatistiksel açıdan anlamlıdır (Figür 2). Ameliyat sonrası 1. ay IGFBP-3 seviyesine kıyasla, ameliyat sonrası 6. ay ( $p: 0,001$; $p<0,01)$ IGFBP-3 seviyesinde izlenen yükselme istatistiksel açıdan oldukça anlamlıdır (Tablo 2).

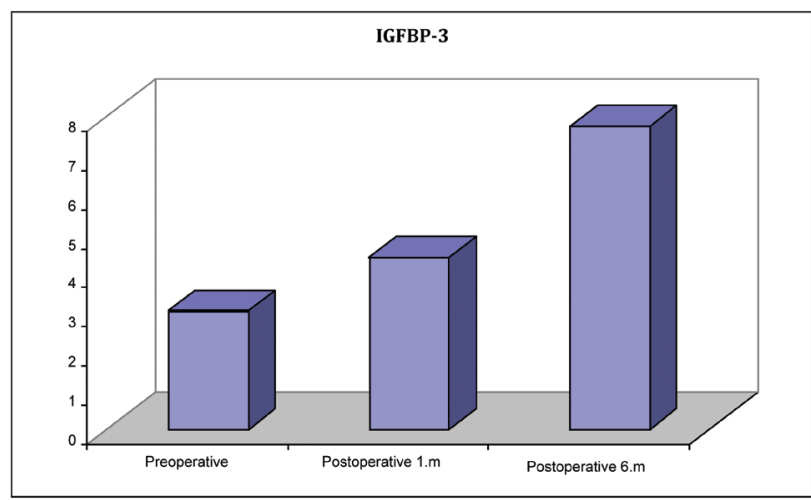

Figür 2. IGFBP-3 değerleri grafiği.

Tablo 2. Preop, postop 1. ay and postop 6. ay serum IGFBP-3 değerleri.

\begin{tabular}{lll}
\hline & $\begin{array}{c}\text { IGFBP-3 } \\
\text { Mean } \pm \text { SD }\end{array}$ & p* \\
\hline Preoperatif & $3,00 \pm 1,17$ & \\
Postoperatif 1. ay & $4,38 \pm 1,14$ & $0,001^{* *}$ \\
Postoperatif 6. ay & $7,70 \pm 1,78$ & \\
Preop-Postop 1. ay $\mathrm{p}^{++}$ & $0,001^{* *}$ & \\
Preop-Postop 6. ay $\mathrm{p}^{++}$ & $0,001^{* *}$ & \\
Postop 1. ay-Postop 6. ay $\mathrm{p}^{++}$ & $0,001^{* *}$ & \\
\hline
\end{tabular}

+Variation Analysis for Repetitive Measurements

${ }^{++}$Paired Sample $t$ test

${ }^{* *} p<0,01$ 
Ameliyat öncesi, ameliyat sonrası 1 . ay ve 6 . ay boy değerleri ortalamaları arasında istatistiksel olarak ciddi düzeyde anlamlı farklılık görülmektedir $(p<0,01)$ (Tablo 3). Ameliyat öncesindeki boy ortalamalarına kıyasla, ameliyat sonrası 1 . ay $(p: 0,001 ; p<0,01)$ ve 6 . ay $(p: 0,001 ; p<0,01)$ boy değerleri ortalamalarında izlenen yükselmeler istatistiksel açıdan oldukça anlamlıdır (Figür 3). Ameliyat sonrası 1. ay boy ortalamasına göre ameliyat sonrası 6 . ay $(p: 0,001 ; p<0,01)$ boy ortalamasında izlenen artma istatistiksel açıdan oldukça anlamlıdır.

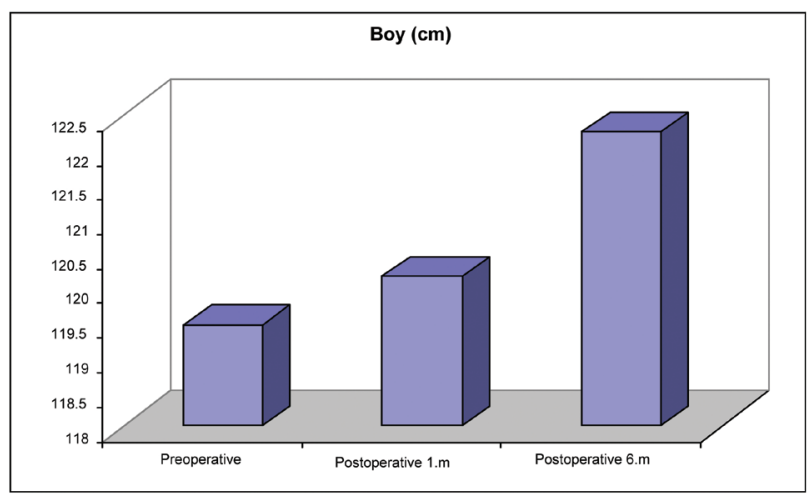

Figür 3. Boy ortalamaları grafiği.

Tablo 3. Preop, postop 1. ay ve postop 6. ay boy ölçümleri (cm).

\begin{tabular}{lll}
\hline & \multicolumn{1}{c}{$\begin{array}{c}\text { Boy }(\mathbf{c m}) \\
\text { Mean } \pm \text { SD }\end{array}$} & p* \\
\hline Preoperatif & $119,46 \pm 15,09$ & \\
Postoperatif 1. ay & $120,17 \pm 14,99$ & $0,001^{* *}$ \\
Postoperatif 6. ay & $122,26 \pm 15,00$ & \\
Preop-Postop 1. ay p $\mathrm{p}^{++}$ & $0,001^{* *}$ & \\
Preop-Postop 6. ay $\mathrm{p}^{++}$ & $0,001^{* *}$ & \\
Postop 1. ay-Postop 6. ay $\mathrm{p}^{++}$ & $0,001^{* *}$ & \\
\hline
\end{tabular}

${ }^{+}$Variation Analysis for Repetitive Measurements

${ }^{++}$Paired Sample t test

$* * p<0,01$

Preoperatif, ameliyat sonrası 1 . ay ve 6 . ay kilo ortalamaları arasında istatistiksel açıdan yüksek değerde anlamlı farklılık gözlenmektedir $(p<0,01)$ (Tablo 4$)$. Ameliyat öncesindeki kilo ortalamasına göre ameliyat sonrası 1 . ay $(p: 0,001 ; p<0,01)$ ve 6 . ay $(p: 0,001 ;$ $p<0,01)$ kilo ortalamalarında gözlenen yükselmeler istatistiksel açıdan anlamlı farklıdır. (Figür 4). Ameliyat sonrası 1. ay kilo ortalamasına göre ameliyat sonrası
6. ay $(p: 0,001 ; p<0,01)$ kilo değerleri ortalamalarında izlenen artma istatistiksel açıdan farklıdır.

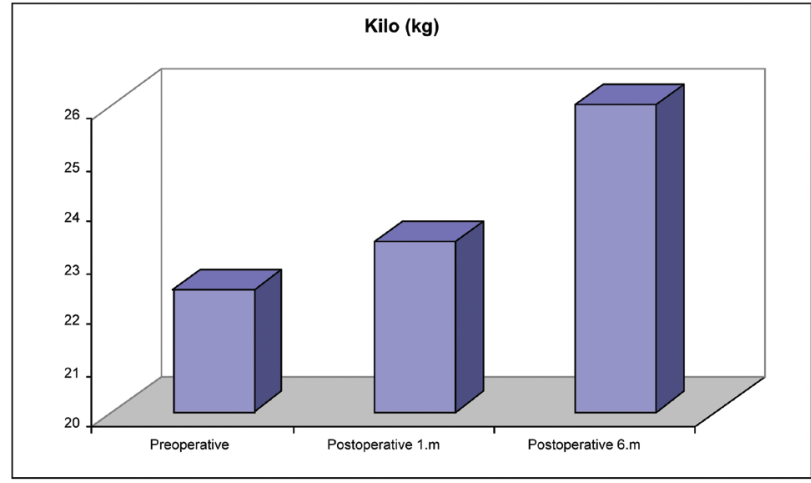

Figür 4. Kilo ortalamaları grafiği.

Tablo 4. Preop, postop 1. ay and postop 6. ay kilo ölçümleri (kg).

\begin{tabular}{lll}
\hline & $\begin{array}{c}\text { Kilo (kg) } \\
\text { Mean } \pm \text { SD }\end{array}$ & p* \\
\hline Preoperatif & $22,37 \pm 7,30$ & \\
Postoperatif 1. ay & $23,33 \pm 7,55$ & $0,001^{* *}$ \\
Postoperatif 6. ay & $25,99 \pm 7,58$ & \\
Preop-Postop 1. ay $\mathrm{p}^{++}$ & $0,001^{* *}$ & \\
Preop-Postop 6. ay $\mathrm{p}^{++}$ & $0,001^{* *}$ & \\
Postop 1. ay-Postop 6. ay $\mathrm{p}^{++}$ & $0,001^{* *}$ & \\
\hline
\end{tabular}

+Variation Analysis for Repetitive Measurements

${ }^{+}$Paired Sample t test

$* * p<0,01$

\section{TARTIŞMA}

Adenotonsillektomi ameliyatı sonrası çocuklarda büyümeve gelişmenin artış gösterdiği yönünde görüşler olmasına rağmen, literatürde bu ilişkiyi araştıran az sayıda calışma bulunmaktadır. Tonsil ve adenoid hipertrofi çocuklarda uyku apne sendromunun en sık görülen nedenidir ${ }^{4}$. Bu hastalığın,çocuklarda büyüme ve gelişmenin duraksamasına neden olduğu gösterilmiş olup, tıkayıcı uyku apnesi sendromu (TUAS) nedeniyle yapılan adenoidektomi ve tonsillektomi operasyonları sonrasında büyüme ve gelişmenin hızlandığı bildirilmiştir ${ }^{5-7}$.

Çocuklarda büyüme ve gelişmeyi düzenleyen büyüme hormonunun (BH) anabolik ve büyümeyi arttırıcı özellikleri karaciğer ve diğer dokulardaki IGF-1 ekspresyonunun stimülasyonu sayesinde olmaktadır ${ }^{8,9}$. 
BH diürnal bir salınıma sahiptir. Bu nedenle günün her saatinde kan düzeyleri farklılık gösterir. Buna ek olarak, BH salınımı uyku siklusu ile de yakından ilişkilidir. Bu nedenle günün herhangi bir saatinde kandan bakılacak $\mathrm{BH}$ seviyeleri gerçek $\mathrm{BH}$ düzeylerini yansıtmayacaktır. Öte yandan, $\mathrm{BH}^{\prime}$ nun indirekt belirteçleri olan IGF-1 ve IGFBP-3'ün serum düzeyleri gün boyunca aynı seviyededir ${ }^{1,2}$. Bu nedenle $\mathrm{BH}$ eksikliğinin belirlenmesinde tarama testi olarak BH'nun ortalama günlük değerini gösteren serum IGF-1 ve IGFBP-3 düzeyleri kullanılmaktadır ${ }^{10,11}$. Diğer taraftan sonuçlar değerlendirilirken yaş, puberte ve beslenme durumu da göz önüne alınmalıdır ${ }^{12}$. IGFBP-3'ün esas fonksiyonu IGF-1'in yarılanma ömrünü arttırmak olmasının yanında, hücreler üzerinde bazı fonksiyonel etkileri de vardır ve IGF-1'e kıyasla BH salınımının güvenilir bir indikatörüdür ${ }^{13,14}$. Ayrıca IGFBP-3 seviyeleri IGF-1 seviyelerinden daha az yaşa bağımlıık göstermektedir ${ }^{15,16}$.

Tonsil ve/veya adenoid hipertrofisi olan hastalarda $\mathrm{BH}$ aksının sekteye uğradığı iyi bilinmesine rağmen, bunun hangi mekanizmalarla olduğu tam olarak bilinmemektedir ${ }^{17}$. Bununla ilgili birtakım teoriler mevcuttur. Bu teorilerin patofizyolojisinde; noktürnal hipoksemi, noktürnal respiratuar asidoz, anoreksiya ve disfaji, beslenme güçlügü, artmış kalori tüketimi ve uyku sırasında artış gösteren solunum eforuna bağlı ortaya çıkan noktürnal BH s salınım bozukluğu şeklindedir. Bu etkenlerin tümünün tonsil ve adenoid hipertofili çocuklarda gelişme geriliğine yol açtığı kanısına varılmaktadır ${ }^{17-19}$.

Aydoğan ve ark. ${ }^{20}$ çalışmalarında, adenoid ve/veya tonsiller hipertrofili hastalarda ameliyat sonrası IGF-1 düzeylerinde anlamlı bir yükselme gözlemediklerini belirtmişlerdir. Bunun nedeninin ise serum IGF düzeylerinin yaş, pubertal gelişim ve beslenme gibi başka faktörlerden de etkilenmesinden dolayı olduğunu belirtmişlerdir. Biz ise çocukların tamamında ameliyat sonrası 1 . ay ve 6 . aylarda IGF-1 seviyelerinde yükselme izledik. Postoperatif erken dönemdeki IGF-1 değerlerimizin artış oranları ameliyat sonrası 6 . aydaki IGF-1 değeri yükseliş oranlarından daha yüksek tespit edildi. Bar ve ark.'nın², Ersoy ve ark.'nın ${ }^{21}$ ve Selimoğlu ve ark.'nın ${ }^{22}$ çalışmalarında, çalışmamızla benzer sonuçlar elde ettiklerini belirledik. Yapılan başka bir çalışmada, ameliyat sonrasıda serum IGF-1 düzeylerinde yükselme bulunduğu fakat, bu yükselme için ameliyattan sonra en az 3 ay geçmesi gerektiğini vurgulamışlardır23. Bunun aksine biz çalışmamızda postoperatif 1 . ayda serum IGF-1 seviyelerinde hızlı bir artış belirledik ve 3 aylık bekleme süresinin gerekli olmadığı sonucuna vardık.

Çalışmamızda, çocukların tamamında ameliyat sonrası 1. ve 6. aylarda serum IGFBP-3 seviyelerinde yükseliş tespit edildi. IGFBP-3 sağlıklı birey serumundaki birincil IGFBP'dir ve açık bir şekilde BH bağımlılığı gösterir. IGFBP-3'ün serum konsantrasyonunun Radyoimmün assay (RIA) kullanılarak belirlenmesinin $\mathrm{BH}$ eksikliği tanısında IGF-1'den daha değerli olduğu düşünülmektedir. Ayrıca IGFBP-3 belirlenmesi yalnızca IGF-1 seviyelerini değil aynı zamanda IGF-2 düzeylerini de işaret ettiğinden dolayı, IGFBP-3'ün belirlenmesinin yaşa bağımlılığı IGF-1'inki kadar belirgin değildir ${ }^{20}$. Ersoy ve ark.'nın, Aydoğan ve ark.'nın ${ }^{20}$, Yılmaz ve ark.'nın ${ }^{23}$ yapmış oldukları çalışmalarında, ameliyat sonrası dönemdeki serum IGFBP-3 düzeyleri bizim postoperatif serum IGFBP-3 düzeyleri ile benzerlik göstermektedir ${ }^{21}$. Ancak Bar ve ark. ${ }^{2}$ ile Selimoğlu ve ark. ${ }^{22}$ serum IGFBP-3 değerlerinde bir yükseliş gördüklerini, bununda nedeninin IGF-1 ve IGFBP sistemlerinin karmaşıklığı olduğunu ileri sürmüşlerdir. Bu sistemler basit tek bir yol ile değil, birçok pozitif ve negatif feedback yolak tarafından kontrol edilmektedir. IGF-1 düzeylerindeki yükselişe eşdeğer oranda IGFBP-3 seviyelerindeki farklılı̆ın eşlik etmemesinin nedeni ise serbest IGF-1 düzeylerindeki artıştır. Buna ek olarak IGF-1 yükselişi olurken IGFPB3'te olmamasını, IGF1'in IGFBP-3'e göre düzenleyicilere daha hassas olması ile açıklamışlardır. Fakat IGFBP-3 seviyelerinde yükselme olmadığını bildiren çalışmaların aksine biz IGFBP-3 düzeylerinde de yükselme tespit ettiğimiz için $\mathrm{BH}$ aksının iyileşmesi ile hem IGF-1 hem de IGFBP-3 düzeylerinin düzeldiği düşüncesine vardık.

Çalışmamızda, çocukların kilo ve boy ölçümlerinin anlamlı biçimde artış gösterdiği saptandı. Tonsiladenoid hipertrofisi ve kronik tonsilliti olan çocuk- 
larda büyüme ve gelişimi gerileten çok sayıda etken vardır. Beslenme zorluğu, yutma güçlüğü, kilo alımda gerilik, üst hava yolu obstrüksiyonu nedeni ile solunum zorluğu sonucu artmış enerji tüketimi ve efor, TUAS'a bağlı gelişen uyku bozuklukları nedeniyle sekteye uğrayan $\mathrm{BH}$ salınımı operasyonun ardından düzeldiği için, çocukların büyüme ve gelişmesinde hızIı bir iyileşme olduğu izlendi. Yapılan bir çalısmada, adenoid ve tonsil hipertrofili çocukların preoperatif dönem boy değerlerinin, sağlıklı kendi yaş gruplarının boy değerlerine kıyasla daha kısa olduğunu, ameliyat sonrasında ise postoperatif birinci senede yaşıtlarıyla aynı ortalamalara eriştiğini bildirmişlerdir. Yine aynı çalışmada postoperatif altıncı ayda kilo değerlerinde belirgin yükselme olduğunu belirtmişlerdir. Büyüme hızındaki bu yükselmeyi beslenme zorluğunun ortadan kalkması, solunum paterninin düzelmesi ve $\mathrm{BH}$ salınım aksının düzelmesine bağlamışlardır ${ }^{21}$. Bar ve ark. $^{2} 13$ adenoid ve tonsil hipertrofili prepubertal çocuğun postoperatif bir yıllık takiplerini yaptıkları çalışmalarında, boy düzeylerinde artış saptamamalarına karşın kilo değerlerinde artış tespit etmişlerdir. Adenoid ve tonsil hipertrofisine sekonder TUAS'lı çocuklarda uyku sırasında oluşan solunum güçlüğünün büyüme ve gelişme geriliğinin en büyük nedeni olarak bozulan $\mathrm{BH}$ salınım aksı olduğu belirtilirken, solunum güçlügünün ortadan kalkması ve $\mathrm{BH}$ salınımının düzelmesiyle kilo artışının oluştuğunu tespit etmişler$\mathrm{dir}^{22}$. Ameliyat sonrası besin maddelerinin daha rahat alınabilmesi ve uykuda harcanan eforun azalmasıyla kilo ve boy seviyelerinde istatistiksel olarak anlamlı yükselişler elde edildiği belirtilmiştir. Yine benzer bir çalışmada ameliyat sonrasında kalori alımının artmaSı, BH aksının düzene girmesi, enerji gereksiniminin azalması ile kilo alımında ve boy uzamasında hızı bir yükseliş gözlemlediklerini bildirmişlerdir ${ }^{20}$. Bizim sonuçlarımızın da literatürle paralellik gösterdiği görülmektedir.

\section{SONUÇ}

Çalışmamızda, tonsil-adenoid hipertrofisi ve/veya kronik tonsillit tanısı ile ameliyat edilen çocuklarda ameliyatın ardından kilo ve boy değerlerinin iyileşmesini, serum IGF-1 ve IGFBP-3 seviyelerinin artışını ve bu yükselişin istatistiksel olarak anlamlı olduğunu saptadık. Bu yükselişin obstrüksiyona bağıı besin alım zorluğu, uyku bozuklukları ve artmış kalori yakımının ortadan kalkması ile oluşabileceğini düşünüyoruz. Değerlerdeki düzelmenin tıkanıklık yakınmaları bulunmayan kronik tonsillitli hastalarda da olmasını ise önceki çalışmalarda iddia edildiği gibi yalnızca tıkanıklıklar nedeniyle bozulmuş BH aksının normale dönmesi ile değil, ayrıca kronik enfeksiyon odağının ortadan kalkmasıyla da ilgili olduğunu düşünüyoruz.

\section{KAYNAKLAR}

1. Blum WF, Albertsson-Wikland K, Rosberg S, Ranke MB. Serum levels of insulin-like growth factor I (IGF-1) and IGF binding protein 3 reflect spontaneous growth hormone secretion. $J$ Clin Endocrinol Metab 1993;76:1610-16.

2. Bar A, Tarasiuk A, Segev Y, et al. The effect of adenotonsillectomy on serum insulin-like growth factor-I and growth in children with obstructive sleep apnea syndrome. J Pediatr 1999;135:76-80.

http://dx.doi.org/10.1016/S0022-3476(99)70331-8

3. Brodsky L, Moore L, Stanievich JF. A comparison of tonsillar size and oropharyngeal dimensions in children with obstructive adenotonsillar hypertrophy. Int J Pediatr Otorhinolaryngol 1987; 13:149-56. http://dx.doi.org/10.1016/0165-5876(87)90091-7

4. Greenfeld M, Tauman R, DeRowe A, Sivan Y . Obstructive sleep apnea syndrome due to adenotonsillar hypertrophy in infants. Int J Pediatr Otorhinolaryngol 2003;67:1055-60. http://dx.doi.org/10.1016/S0165-5876(03)00182-4

5. Everett AD, Koch WC, Saulsbury FT. Failure to thrive due to obstructive sleep apnea. Clin Pediatr 1987;26:90-2. http://dx.doi.org/10.1177/000992288702600206

6. Bate TW, Price DA, Holme CA, McGucken RB . Short stature caused by obstructive apnoea during sleep. Arch DisChild 1984;59:78-80.

http://dx.doi.org/10.1136/adc.59.1.78

7. Nieminen $P$, Löppönen $T$, Tolonen $U$, et al. Growth and biochemical markers of growth in children with snoring and obstructive sleep apnea. Pediatrics 2002;109:55. http://dx.doi.org/10.1542/peds.109.4.e55

8. Ohlsson C, Bengtsson BA, Isaksson OG, et al. Growth hormone and bone. Endocr Rev 1998;19:55-79. http://dx.doi.org/10.1210/er.19.1.55

9. Daughaday $\mathrm{WH}$, Rotwein $\mathrm{P}$. Insulin-like growth factors I and II. Peptide, messenger ribonucleic acid and gene structures, serum, and tissue concentrations. Endocr Rev 1989;10:6891.

http://dx.doi.org/10.1210/edrv-10-1-68

10. Barkan AL, Beitins IZ, Kelch RP. Plasma insulin-like growth factor-I/somatomedin-C in acromegaly: correlation with the degree of growth hormone hypersecretion. J Clin Endoerinol Metab 1988;67:69-73. http://dx.doi.org/10.1210/jcem-67-1-69

11. Melmed S. Acromegaly. N Engl J Med 1990;322:966-77. http://dx.doi.org/10.1056/NEJM199004053221405

12. Lee PD, Wilson DM, Rountree $L$, et al. Efficacy of insulin-like 
growth factor I levels in predicting the response to provocative growth hormone testing. Pediatr Res 1990;27:45-51. http://dx.doi.org/10.1203/00006450-199001000-00015

13. Rosenfeld RG, Hwa V, Wilson L, et al. The insulin-like growth factor binding protein superfamily: new perspectives. Pediatrics 1999;104:1018-21.

14. Blum WF, Albertsson-Wikland K, Rosberg S, Ranke MB.Serum levels of insulin-like growth factor I (IGF-I) and IGF binding protein 3 reflect spontaneous growth hormone secretion. $J$ Clin Endocrinol Metab 1993;76:1610-16.

15. Argente J, Caballo N, Barrios V et al. Multiple endocrine abnormalities of the growth hormone and insulin-like growth factor axis in prepubertal children with exogenous obesity: effect of short- and long-term weight reduction. J Clin Endocrine Metab 1997;82:2076-83. http://dx.doi.org/10.1210/jc.82.7.2076

16. Palacio AC, Pérez-Bravo F, Santos JL, et al. Leptin levels and IgF-binding proteins in malnourished children: effect of weight gain. Nutrition 2002; 18:17-19. http://dx.doi.org/10.1016/S0899-9007(01)00690-6

17. Bate TW, Price DA, Holme CA, McGucken RB . Short stature caused by obstructive apnoea during sleep. Arch DisChild 1984;59:78-80.

http://dx.doi.org/10.1136/adc.59.1.78
18. Marcus CL, Carroll JL, Koerner CB, et al. Determinants of growth in children with the obstructive sleep apnea syndrome. J Pediatr 1994;125:556-62. http://dx.doi.org/10.1016/S0022-3476(94)70007-9

19. Bland RM, Bulgarelli S, Ventham JC, et al. Total energy expenditure in children with obstructive sleep apnoea syndrome. Eur Respir J 2001;18:164-9.

http://dx.doi.org/10.1183/09031936.01.99104401

20. Aydogan M, Toprak D, Hatun S, et al. The effect of recurrent tonsillitis and adenotonsillectomy on growth in childhood. Int J Pediatr Otorhinolaryngol 2007;71:1737-42. http://dx.doi.org/10.1016/j.ijporl.2007.07.012

21. Ersoy B, Yücetürk AV, Taneli $F$, et al. Changes in growthpattern, body composition and markers of growth after adenotonsillectomy in prepubertal children. IntJ Pediatr Otolaryngol 2005;69:1175-81. http://dx.doi.org/10.1016/j.ijporl.2005.02.020

22. Selimoğlu E, Selimoğlu MA, Orbak Z. Does adenotonsillectomy improve growth in children with obstructive adenotonsillar hypertrophy? J Int Med Res 2003;31:84-7. http://dx.doi.org/10.1177/147323000303100204

23. Yilmaz MD, Hoşal AS, Oğuz $\mathrm{H}$, et al. The effects of tonsillectomy and adenoidectomy on serum IGF-I andIGFBP3 levels in children. Laryngoscope 2002;112:922-5. http://dx.doi.org/10.1097/00005537-200205000-00026 